\title{
Jurist-Diction
}

Volume 3 No. 6, November 2020

\section{Ketidaksesuaian Ketentuan Jaminan Sosial Dalam Undang- Undang Nomor 24 Tahun 2011 dan Peraturan Pemerintah Nomor 70 Tahun 2015}

\author{
Hafidh Arighi \\ hafidh.arighi-2016@fh.unair.ac.id \\ Universitas Airlangga
}

How to cite:

Hafidh Arighi,'Ketidaksesuaian

Ketentuan Jaminan Sosial

Dalam Undang-Undang Nomor

24 Tahun 2011 Dan Peraturan

Pemerintah Nomor 70 Tahun

2015' (2020) Vol. 3 No. 6

November Jurist-Diction.

Histori artikel:

Submit 9 Agustus 2020;

Diterima 12 September 2020;

Diterbitkan 1 November 2020.

DOI:

10.20473/jd.v3i6.22968

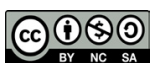

\begin{abstract}
Abstrak
Dibentuknya Peraturan Pemerintah Nomor 70 Tahun 2015 Tentang Jaminan Kecelakaan Kerja dan Jaminan Kematian bagi Aparatur Sipil Negara menimbulkan kontroversi Pada Pasal 7 Peraturan Pemerintah Nomor 70 Tahun 2015 Tentang Jaminan Kecelakaan Kerja dan Jaminan Kematian Bagi Aparatur Sipil Negara menyebutkan bahwa jaminan kecelakaan kerja dan jaminan kematian bagi Aparatur Sipil Negara dikelola oleh PT TASPEN dan oleh sebab itu bertentangan dengan ketentuan yang ada dalam Undang-Undang Nomor 40 Tahun 2004 Tentang SJSN, Undang-Undang Nomor 24 Tahun 2011 Tentang BPJS dan juga Peraturan Presiden Nomor 109 Tahun 2013 Tentang Penahapan Kepesertaan Program Jaminan Sosial. Hasil dari penelitian ini menurut Putusan Mahkamah Agung Nomor 32 P/HUM/2016 dan Putusan Mahkamah Konstitusi Nomor 98/PUU-XV/2017 yang menyatakan bahwa Peraturan Pemerintah Nomorr 70 Tahun 2015 Tentang Jaminan Kecelakaan Kerja dan Jaminan Kematian bagi Aparatur Sipil Negara tidak bertentangan dengan Undang-Undang Nomor 40 Tahun 2004 Tentang SJSN, Undang-Undang Nomor 24 Tahun 2011 Tentang BPJS dan juga Peraturan Presiden Nomor 109 Tahun 2013 Tentang Penahapan Kepesertaan Program Jaminan Sosial. Kata Kunci: Jaminan Sosial; Pegawai Negeri Sipil; Jaminan Kecelakaan Kerja; jaminan kematian.
\end{abstract}

\section{Pendahuluan}

PT TASPEN atau PT Dana Tabungan dan Asuransi Pegawai Negeri (persero) merupakan Badan Usaha Milik Negara atau biasa disebut BUMN yang memiliki peran untuk menyelenggarakan program asuransi sosial Pegawai Negeri Sipil (PNS) yang terdiri atas Program Jaminan Kecelakaan Kerja (JKK), Program Jaminan kematian (JKM), Program Pensiun Pegawai Negeri Sipil (PNS) dan Tabungan Hari Tua (THT) dengan tujuan untuk meningkatkan kesejahteraan Pegawai Negeri pada 
saat memasuki usia pensiun. ${ }^{1}$ Dalam rangka menjadi perusahaan yang memfokuskan diri sebagai perusahaan yang melayani jaminan sosial bagi Aparatur Sipil Negara (ASN) berdasarkan Pasal 92 ayat (4) dan Pasal 107 UU Nomor 5 Tahun 2014, pada tahun 2015 pemerintah mengeluarkan Peraturan Pemerintah Nomor 70 Tahun 2015 tentang Jaminan Kecelakaan Kerja dan Jaminan Kematian Bagi Pegawai Aparatur Sipil Negara. Tetapi dengan dibentuknya PP No. 70 Tahun 2015 tersebut terdapat ketidaksinkronan terhadap UU No. 24 Tahun 2011 Tentang Badan Penyelenggara Jaminan Sosial.

Badan Penyelenggara Jaminan Sosial (BPJS) yang diatur dalam UndangUndang Nomor 24 Tahun 2011 tentang Badan Penyelenggara Jaminan Sosial merupakan badan hukum yang dibentuk untuk menyelenggarakan program jaminan sosial. ${ }^{2}$ Terdapat 2 (dua) jenis BPJS yaitu yang pertama BPJS kesehatan yang merupakan bentuk dari peleburan PT Asuransi Kesehatan (askes) (persero), tugas BPJS Kesehatan ini memberikan perlindungan kesehatan secara mendasar bagi seluruh rakyat Indonesia, tanpa terkecuali. Yang kedua BPJS ketenagakerjaan merupakan bentuk peleburan dari PT Jamsostek (Persero), yang memiliki Tugas memberikan perlindungan terhadap tenaga kerja Indonesia, baik mereka yang bekerja secara informal maupun nonformal. ${ }^{3}$

Dalam PP No. 70 Tahun 2015 Tentang Jaminan Kecelakaan Kerja dan Jaminan Kematian Bagi Pegawai Aparatur Sipil Negara pada Pasal 4 menyatakan bahwa yang peserta Jaminan Kecelakaan Kerja (JKK) dan Jaminan Kematian (JKM) adalah calon PNS, PNS, dan PPPK. Pada pasal 7 PP No. 70 Tahun 2015 menyatakan bahwa peserta JKK dan JKM dikelola oleh PT Dana Tabungan dan Asuransi Pegawai Negeri sehingga ketentuan tersebut bertentangan dengan UU No. 24 Tahun 2011 Tentang

\footnotetext{
${ }^{1}$ Admin web TASPEN, 'Sejarah perusahaan', <https://www.taspen.co.id/\# /history?_k=liqru7> accesed 09 Februari 2020.

${ }^{2}$ Undang-Undang Nomor 24 Tahun 2011 Tentang Badan Penyelenggara Jaminan Sosial (Lembaran Negara Republik Indonesia Tahun 2011 Nomor 116, Tambahan Lembaran Negara Republik Indonesia Nomor 5256).

3 Admin web BPJS, 'ini Beda BPJS Ketenagakerjaan dan BPJS Kesehatan' (bpjsketenagakerjaan,2015)<https:/www.bpjsketenagakerjaan.go.id/berita/1253/Ini-Beda-BPJS Ketenagakerjaan-\&-BPJS-Kesehatan.html>, accesed 09 Februari 2020.
} 
BPJS dan UU No. 40 Tahun 2004 tentang SJSN, dalam Peraturan Presiden Nomor 109 tahun 2013 Tentang Penahapan Kepersertaan Program Jaminan Sosial pada Pasal 2 ayat (4) menyebutkan bahwa program jaminan kematian, Program jaminan kecelakaan kerja, Program jaminan hari tua, dan Program jaminan pensiun ASN dikelola oleh BPJS Ketenagakerjaan, dan maka dari itu semestinya tidak boleh lagi ada badan selain BPJS Ketenagakerjaan yang mengelola Program jaminan Sosial tersebut. Kecuali dengan Program Jaminan pensiun yang menurut UU No. 24 Tahun 2011 Pasal 65 ayat (2) menyebutkan bahwa PT TASPEN (Persero) menyelesaikan pengalihan program tabungan hari tua dan program pembayaran pensiun dari PT TASPEN (persero) ke BPJS Ketenagakerjaan paling lambat tahun 2029.

\section{Metode Penelitian}

Tipe penelitian hukum yang digunakan dalam penelitian hukum ini adalah Doctrinal Research, dalam melakukan penelitian hukum ini wajib membuat eksposisi sistematis yang menghubungkan peraturan perundang-undangan yang ada dengan tujuan untuk memberikan pembangunan hukum dimasa yang akan datang.

\section{Sistem Jaminan Sosial Nasional}

Di dalam Undang-Undang Dasar 1945 terselip konsepsi tanggung jawab negara dalam hak asasi manusia (state responsibilities), sebagaimana terlihat dalam pasal $28 \mathrm{I}$ (4) dan (5), yang menyatakan "Perlindungan, pemajuan, penegakan, dan pemenuhan hak asasi manusia adalah tanggung jawab negara, terutama pemerintah dan untuk menegakkan dan melindungi hak asasi manusia sesuai dengan prinsip negara hukum yang demokratis, maka pelaksanaan hak asasi manusia dijamin, diatur, dan dituangkan dalam peraturan perundang-undangan" keduanya merupakan kunci dalam melihat tanggung jawab konstitusional yang harus dilakukan oleh negara, dalam hal ini pemerintah, untuk melaksanakan upaya-upaya pemajuan hak asasi manusia. ${ }^{4}$

\footnotetext{
${ }^{4}$ R.Herlambang Perdana Wiratraman, 'Konstitusionalisme \& Hak-Hak Asasi Manusia Konsepsi Tanggung Jawab Negara Dalam Sistem Ketenagakerjaan’ (2005) 20 Jurnal Ilmu Hukum YURIDIKA.[9].
} 
Sistem Jaminan Sosial Nasional (SJSN) ini merupakan program negara yang bertujuan untuk memberikan kepastian perlindungan hak asasi manusia dan kesejahteraan sosial bagi seluruh rakyat sebagaimana tercantum dalam UndangUndang Dasar Republik Indoneisa Pasal 28H ayat (1) yang menyebutkan " Setiap orang berhak hidup sejahtera lahir dan batin, bertempat tinggal, dan mendapatkan lingkungan hidup yang baik dan sehat serta berhak memperoleh pelayanan kesehatan.”, ayat (2) yang menyebutkan “Setiap orang berhak mendapat kemudahan dan perlakuan khusus untuk memperoleh kesempatan dan manfaat yang sama guna mencapai persamaan dan keadilan.", dan ayat (3) yang menyebutkan "Setiap orang berhak atas jaminan sosial yang memungkinkan pengembangan dirinya secara utuh sebagai manusia yang bermartabat." dan Pasal 34 ayat (1) yang menyebutkan "Fakir miskin dan anak-anak terlantar dipelihara oleh negara." dan ayat (2) yang menyebutkan bahwa "Negara mengembangkan sistem jaminan sosial bagi seluruh rakyat dan memberdayakan masyarakat yang lemah dan tidak mampu sesuai dengan martabat kemanusiaan". 5

Menurut Undang-Undang Nomor 40 Tahun 2004 tentang Sistem Jaminan Sosial Pasal 1 Angka (2) menyebutkan bahwa Sistem Jaminan Sosial adalah suatu tata cara penyelenggaraan program jaminan sosial oleh beberapa badan penyelenggara jaminan sosial. Dalam Pasal 18 Undang-Undang Nomor 40 Tahun 2004 tentang SJSN, jenis program Jaminan Sosial Nasional meliputi lima program yaitu:

1. Jaminan Kecelakaan Kerja

Jaminan sosial ini diberikan kepada tenaga kerja yang mengalami suatu peristiwa yang tidak diinginkan saat melakukan pekerjaannya dan terjadi di lingkungan kerja berhak mendapatkan manfaat berupa uang tunai dan pelayanan kesehatan.

2. Jaminan kematian

Jaminan sosial ini diberikan kepada ahli waris peserta yang meninggal dunia dan kematiannya bukan akibat dari kecelakaan kerja atau yang berhubungan dengan likungan kerja.

3. Jaminan kesehatan

Setiap peserta dari jaminan sosial ini diberikan perlindungan kesehatan. Jaminan kesehatan memiliki tujuan menjamin agar peserta memperoleh manfaat pemeliharaan kesehatan dan perlindungan dalam memenuhi kebutuhan dasar

${ }^{5}$ Undang-Undang Dasar Negara Republik Indonesia Tahun 1945. 
kesehatan.

4. Jaminan Hari tua

Pada jaminan ini pemberian maanfaat diberikan langsung kepada peserta yang memasuki usia pensiun, cacat total, dan meninggal dunia.

5. Jaminan Pensiun

Dalam jaminan sosial ini bertujuan untuk meningkatkan kesejahteraan perserta dan ahli warisnya apabila peserta sudah memasuki usia pensiun, cacat total, atau meninggal. Pemberian maanfaat berupa pemberian penghasilan. ${ }^{6}$

Agar program-program jaminan sosial diatas dapat terlaksana sesuai dengan tujuan Sistem Jaminan Sosial Nasional, yakni untuk memberikan jaminan terpenuhinnya kebutuhan dasar hidup yang layak bagi peserta dan atau anggota keluargannya. Berdasarkan pasal 2 UU SJSN, penyelenggaraan jaminan sosial harus berdasarkan asas kemanusiaan, asas manfaat, dan asas keadilan. Asas kemanusiaan yang berkaitan dengan penghargaan terhadap martabat manusia, asas manfaat merupakan asas yang bersifat operasional menggambarkan pengelolaan yang efisien dan efektif, Asas keadilan merupakan asas yang bersifat ideal. ${ }^{7}$

BPJS dibentuk berdasarkan UU No. 24 Tahun 2011 Berdasarkan Pasal 5 UU No. 24 Tahun 2011 menyebutkan bahwa ada 2 macam BPJS yaitu yang terduri atas BPJS kesehatan dan BPJS ketenagakerjaan yang dimana kedua jeni BPJS ini berfungsi untuk menyelenggarakan program jaminan kesehatan, program jaminan kecelakaan kerja, program jaminan kematian, program jaminan pensiun, dan jaminan hari tua. Jauh sebelum itu penyelenggaraan program jaminan sosial pada saat belum di bentuknya BPJS telah diselenggarakan oleh badan hukum privat yang berbentuk BUMN, yaitu PT Jamsostek, PT Askes, PT ASABRI, dan PT Taspen. Pogram Jaminan sosial yang terdapat pada UU No. 24 Tahun 2011 sesungguhnya telah diselenggarakan oleh keempat perusahaan perseroan tersebut yang pada saat itu sesuai dengan tugas dan bidang masing-masing. Namun penyelenggaraannya belum dilakukan secara menyeluruh, terintegrasi, terstandar dan terukur, baik di

${ }^{6}$ Undang-Undang Nomor 40 Tahun 2004 Tentang Sistem Jaminan Sosial (Lembaran Negara Republik Indonesia Tahun 2004 Nomor 150, Tambahan Lembaran Negara Republik Indonesia Nomor 4456).

${ }^{7}$ Budi Susanto, 'Analisis Yuridis Kewenangan Pengelolaan Program Jaminan Kecelakaan Kerja Bagi Aparatur Sipil Negara’ (2017) 10 Arena Hukum.[391]. 
bidang keperataan, iuran maupun pemberian manfaat kepada peserta. Dalam penyelenggaraan program jaminan sosial, masing-masing persero mempunyai standar dan ukuran sendiri-sendiri dan lebih bersifat parsial dan tidak menyeluruh. Badan penyelenggara jaminan sosial tersebut Selain berbadan hukum publik, penyelenggraannya juga berbentuk badan usaha yang lebih mencari keuntungan. Jadi, penyelenggaraan jaminan sosial tersebut merupakan kegiatan usaha atau bisnis semata, walaupun bentuk badan usahanya adalah BUMN yang mempunyai tanggung jawab untuk memberikan pelayanan umum.

\section{Kepesertaan Aparatur Sipil Negara dalam BPJS dan PT TASPEN}

Aparatur Sipil Negara (ASN) merupakan profesi bagi Pegawai Negeri Sipil (PNS) dan pegawai pemerintahan yang terikat oleh perjanjian kerja yang berada pada instansi pemerintah. Pegawai ASN ini diangkat oleh pejabat pembina kepegawaian dan diberikan tugas dalam jabatan pemerintahan atau tugas negara lainnya, dan juga diberikan gaji sesuai dengan peraturan perundang-undangan yang berlaku. Pegawai Aparatur Sipil Negara memiliki fungsi yaitu sebagai pelayanan public, sebagai pelaksana kebijakan publik, dan juga termasuk sebagai pemersatu bangsa. Selain fungis Aparatur Sipil Negara memiliki tugas yaitu memberikan pelayanan publik yang baik dan berkualitas, melaksanakan kebijakan publik yang dibuat oleh pejabat pembina kepegawaian yang sesuai dengan peraturan perundang-undangan, serta Aparatur Sipil Negara memiliki tugas sebagai pelaksana, perencana, dan pengawas penyelenggaraan tugas umum pemerintahan dan pembangunan nasional melalui pelaksanaan kebijakan dan pelayanan publik secara professional.

Untuk melaksanakan UU ASN, maka Presiden pada tanggal 16 September 2015 menetapkan Peraturan Pemerintah Nomor 70 Tahun 2015 tentang Jaminan Kecelakaan Kerja dan Jaminan Kematian bagi Pegawai Aparatur Sipil Negara yang mulai berlaku sejak tanggal 1 Juli 2015. Dalam Pasal 7 disebutkan bahwa Peserta adalah Peserta Jaminan Kecelakaan Kerja dan Jaminan Kematian yang dikelola oleh PT. TASPEN (Persero). Jika dianalisis dengan peraturan perundang-undangan di atasnya, yakni produk hukum UU yang terkait dengan Sistem Jaminan Sosial 
Nasional, khususnya untuk Program Jaminan Kecelakaan Kerja dan Program Jaminan Kematian, maka nampak substansi Pasal 7 Peraturan Pemerintah No. 70 Tahun 2015 bertentangan dengan:

a. Pasal 1 angka 6 UU SJSN dan Pasal 1 angka 1 UU BPJS bahwa yang berwenang menyelenggarakan program Jaminan Sosial Nasional yang meliputi Jaminan Kesehatan, Jaminan Kecelakaan Kerja, Jaminan Hari Tua, Jaminan Pensiun, dan Jaminan Kematian untuk seluruh penduduk Indonesia, termasuk di dalamnya pegawai Aparatur Sipil Negara, adalah Badan Penyelenggara Jaminan Sosial (BPJS). Berdasarakan Pasal 5 ayat (1) UU SJSN, BPJS harus dibentuk dengan produk hukum UU yang kemudian pada tahun 2011 terbit UU No. 24 Tahun 2011 yang mengatur pembentukan BPJS. Berdasarkan Pasal 5 ayat (2) UU BPJS, hanya ada nya Badan Penyelenggara Jaminan Sosial yaitu BPJS Kesehatan dan BPJS Ketenagakerjaan. Berdasarkan Pasal 7 ayat (1) UU BPJS disbetukan bahwa BPJS berstatus Badan Hukum Publik. Berdasarkan Pasal 4 hruf b UU BPJS disebutkan bahwa BPJS menyelenggarakan sistem jaminan sosial nasional dengan menggunakan prinsip niralaba. Sebaliknya, PT. TASPEN (Persero) bukan Badan Penyelenggara Jaminan Sosial yang dibentuk dengan hukum Undang-Undang dan berstatus Badan Hukum Publik. PT. TASPEN (Persero) adalah Badan Usaha Milik Negara (BUMN) yang dibentuk dengan Peraturan Pemerintah Nomor 26 Tahun 1981 tentang Pengalihan Bentuk Perusahaan Umum Dana Tabungan dan Asuransi Pegawai Negeri menjadi Perusahaan Perseroan (Persero) adalah Badan Usaha Milik Negara (BUMN) yang menurut Pasal 2 ayat (1) huruf b UU 19 Tahun 2003 tentang Badan Usaha Milik Negara, maksud dan tujuan BUMN adalah untuk mengejar keuntungan, jelas hal ini bertentangan dengan prinsip penyelenggaraan BPJS yaitu niralaba. Hal ini juga sudah secara tegas dinyatakan oleh Mahkamah Konstitusi dalam Putusannya tanggal 31 Agustus 2005 terhadap Perkara Nomor 007/PUU-III/2005 bahwa status hukum PT. TASPEN, PT. ASABRI, PT Jamsostek, dan PT Askes tidak sesuai dengan kehendak yang ingin diwujudkan dalam UU SJSN. Pasal 5 ayat (2) dan ayat (3) UU SJSN yang menyatakan ke-empat Persero tersebut sebagai BPJS dinyatakan bertentangan dengan UUD 1945 dan tidak mempunyai kekuatan mengikat.

b. Pasal 13 ayat (1) UU SJSN dan Pasal 15 ayat (1) UU BPJS yang menyebutkan bahwa Pemberi Kerja secar bertahap wajib mendaftarkan dirinya dan pekerjaannya sebagai Peserta kepada BPJS sesuai dengan program jaminan sosial yang diikuti. Berdasarkan Pasal 13 ayat (2) UU SJSN dan Pasal 15 ayat (3) UU BPJS bahwa penahapan sebagaimana Pasal 13 ayat (1) UU SJSN dan Pasal 15 ayat (1) UU BPJS diatur dengan Peraturan Presiden. Dalam Pasal 5 ayat (2) dan (3) Peraturan Presiden Nomor 109 Tahun 2013 tentang Penahapan Kepesertaan Program Jaminan Sosial yang merupakan peraturan pelaksanaan dari pasal 13 ayat (2) UU SJSN dan Pasal 15 ayat (3) UU BPJS disebutkan bahwa penyelenggara negara wajib mendaftarkan pekerjanya yang meliputi calon pegawai negeri sipil, pegawai negeri sipil, anggota TNI, anggota PORLI, pejabat negara, pegawai pemerintah non pegawai negeri, prajurit TNI dan peserta 
didik PORLI dalam program Jaminan Kecelakaan Kerja, Program Jaminan Hari Tua, Program Jaminan Pensiun, dan Program Jaminan Kematian secara bertahap kepada BPJS Ketenagakerjaan. Penahapan dimulainnya pendaftaran bagi pekerja yang bekerja pada pemberi kerja penyelenggara negara dilakukan untuk program Jaminan Kecelakaan kerja dan Jaminan Kematian paling lambat 1 Juli 2015.

c. Pasal 57 huruf f UU BPJS yang mengatur bahwa Perusahaan perseroan (persero) PT Dana Tabungan dan Asuransi Pegawai Negeri atau disingkat PT. TASPEN (Persero) tetap melaksanakan kegiatan operasional penyelenggaraan program Tabungan Hari Tua dan program Pembayaran Pensiun bagi pesertannya, termasuk penambahan peserta baru, sampai dengan dialihkan ke BPJS Ketenagakerjaan, jadi Pasal 57 huruf f UU BPJS secara jelas menyebutkan bahwa PT. TASPEN (Peresro) hanya diperkenankan untuk menambah peserta baru, bukan menambah program jaminan sosial baru. Penambahan peserta baru hanya dilakukan pada program yang sudah dijalankan oleh PT. TASPEN (Persero), yaitu Program Tabungan Hari Tua dan Program Pembayaran Pensiun bagi pesertannya sampai dengan dialihkan ke BPJS Ketenagakerjaan.

d. Pasal 92 ayat (2) UU ASN yang menegaskan bahwa perlindungan kepada pegawai Aparatur Sipil Negara yang berupa Jaminan Kesehatan, Jaminan Kecelakaan kerja, dan Jaminan Kematian mencakup jaminan sosial yang diberikan dalam program Jaminan Sosial Nasional. Artinya baik program jaminan sosial maupun penyelenggara jaminan sosial dilaksanakan sesuai dengan peraturan perundangundangan yang mengatur Jaminan Sosial Nasional yaitu UU SJSN dan UU BPJS.

Peraturan Pemerintah No. 70 Tahun 2015 ini menyebabkan pertentangan dengan peraturan perundang-undangan di atasnya, meskipun telah adanya perubahan Peraturan Pemerintah No. 70 Tahun 2015 dengan Peraturan Pemerintah No. 66 Tahun 2017 tetapi tidak merubah Pasal 7 Peraturan Pemerintah No 70 Tahun 2015 . Hingga sekarang Peraturan Pemerintah No. 70 Tahun 2015 ini tetap berlaku, dengan diperkuat dengan adanya putusan MA Nomor 32P/HUM/2016 dan MK Nomor 98/PUU-XV/2017 yang menyatakan bahwa PP 70 Tahun 2015 tidak bertentangan dengan UU diatasnya dan maka dari itu pengelolaan JKK dan JKM bagi ASN tetap merupakan wewenang dari PT TASPEN, hal ini mengakibatkan PT. Taspen (Persero) meminta iuran yang telah dibayarkan pemerintah daerah ke BPJS Ketenagakerjaan atas keikutsertaannya dalam program Jaminan Kecelakaan Kerja dan Jaminan Kematian sejak Juli 2015.

Apabila pegawai ASN menjadi Pejabat Negara dan diberhentikan sementara sebagai pegawai ASN maka penyelenggara Jaminan Kecelakaan Kerja dan 
Jaminan Kematiannya adalah BPJS. Sementara dalam Peraturan Pemerintah Nomor 70 Tahun 2015 tentang Jaminan Kecelakaan Kerja dan Jaminan Kematian bagi Pegawai Aparatur Sipil Negara tidak diatur mengenai Pegawai ASN yang diberhentikan sementara karena menjadi Pejabat Negara karena dalam Peraturan Pemerintah tersebut yang menjadi pesertanya hanyalah Calon PNS, PNS dan PPPK. ${ }^{8}$

\section{Upaya Hukum yang Dapat Ditempuh oleh ASN yang Tidak Didaftarkan BPJS Ketenagakerjaan Terkait dengan Jaminan Kematian dan Jaminan Kecelakaan Kerja}

Dalam Undang-Undang Nomor 40 Tahun 2004 tentang Sistem Jaminan Sosial Nasional setiap tenaga kerja wajib mendapatkan jaminan sosial dan pemberi kerja wajib mendaftarkan pegawainya. Sehingga dapat diketahui bahwa jaminan sosial merupakan hak bagi semua pekerja. ${ }^{9}$

Instansi pemerintah tidak termasuk dalam subjek yang terdapat pada Pasal 1 angka 6 dan angka 7 Undang-Undang Nomor 2 Tahun 2004 maka dari itu Aparatur Sipil Negara (ASN) tidak termasuk subjek dari PHI. Menurut Pasal 1 angka 6 Pemberi kerja bagi ASN adalah penyelenggara negara yang mempekerjakan Pegawai ASN pada Pemerintah Pusat dan Pemerintah Daerah. maka dari itu apabila terjadi perselisihan antara ASN maka termasuk dalam sengketa kepegawaian.

Dikeluarkannya Keputusan Tata Usaha Negara (KTUN) yang terkait dengan kepegawaian atau yang lebih dikenal sebagai Surat Keputusan (SK) dari pejabat pemerintahan tertentu dapat menyebabkan sengketa kepagawaian, contohnya seperti SK pengangkatan pegawai, pemberhentian pegawai baik atas permohonan sendiri maupun bukan atas permohonan sendiri, SK mutasi, SK

8 Peraturan Pemerintah Nomor 70 Tahun 2015 Tentang Jaminan Kecelakaan Kerja dan Jaminan Kematian Bagi Aparatur Sipil Negara (Lembaran Negara Republik Indonesia Tahun 2015 Nomor 212, Tambahan Lembaran Negara Republik Indonesia Nomor 5740).

9 Undang-Undang Nomor 40 Tahun 2004 Tentang Sistem Jaminan Sosial (Lembaran Negara Republik Indonesia Tahun 2004 Nomor 150, Tambahan Lembaran Negara Republik Indonesia Nomor 4456). 
penjatuhan sanksi administrasi kepegawaian, SK penjatuhan disiplin PNS, dan lain-lain. ${ }^{10}$

Akibat tidak diterimanya atau tidak setuju dengan ketentuan Surat Keputusan yang dikeluarkan oleh suatu pejabat pemerintahan tertentu untuk Aparatur sipil Negara dan dirasa tidak ada kesesuaian sehingga dianggap merugikan Aparatur Sipil Negara. Dalam Undang-Undang Nomor 9 Tahun 2004 tentang perubahan atas Undang-Undang Nomor 5 Tahun 1986 tentang Peradilan Tata Usaha Negara disbeutkan bahwa sengketa Kepegawaian terjadi apabila seorang Pegawai Negeri Sipil yang mendapatkan Surat Keputusan (SK) merasa mendapatkan kerugian sebagai akibat dari di Keluarkannya SK tersebut. Dalam hal ini yang bersangkutan akan memposisikan dirinya sebagai penggugat.

Sengketa kepegawaian merupakan salah satu bagian dari sengketa tata usaha negara. Pengertian mengenai sengketa tata usaha negara diatur dalam Pasal 1 angka 10 Undang-Undang Nomor 51 Tahun 2009 tentang Peradilan Tata Usaha Negara yang menyebutkan bahwa Sengketa Tata Usaha Negara adalah sengketa yang timbul dalam bidang tata usaha negara antara orang atau badan hukum perdata dengan badan atau pejabat tata usaha negara, baik di pusat maupun di daerah, sebagai akibat di keluarkannya keputusan tata usaha negara, termasuk sengketa kepegawaian berdasarkan peraturan perundang-undangan yang berlaku. ${ }^{11}$ Dalam Undang-Undang Nomor 5 Tahun 2014 tentang Aparatur Sipil Negara lahir Badan pertimbangan Aparatur Sipil Negara atau Badan Pertimbangan ASN yang bertugas menerima banding administratif yang diajukan oleh Aparatur Sipil Negara yang bersengketa. Untuk penyelesaian sengketa kepegawaian ini diatur dalam Pasal 129 Undang-Undang Nomor 5 Tahun 2014.

\footnotetext{
${ }^{10}$ Adrian E. Rompis, et al, 'Perbandingan Penyelesaian Sengketa Kepegawaian Melalui Gugatan Di Peradilan Tata Usaha Negara Dan Upaya Banding Administrasi Di Badan Pertimbangan Kepegawaian' (2012) 6 Jurnal Kebijakan dan Manajemen PNS.[4].

${ }^{11}$ Undang-Undang Nomor 51 Tahun 2009 Tentang Peradilan Tata Usaha Negara (Lembaran Negara Republik Indonesia Tahun 2009 Nomor 160, Tambahan Lembaran Negara Republik Indonesia Nomor 5079).
} 


\section{Kesimpulan}

Bahwa kewenangan pengelolaan program JKK dan JKM untuk pegawai negeri atau ASN oleh PT TASPEN berdasarkan pasal 7 Peraturan Pemerintah Nomor 70 Tahun 2015 tentang Jaminan Kecelakaan Kerja dan Jaminan Kematian bagi Pegawai Aparatur Sipil Negara bertentangan dengan: Pasal 1 angka 6, Pasal 13 ayat (1) UU Np. 40 Tahun 2004 tentang Sistem Jaminan Sosial Nasional; pasal 1 angka 1, Pasal 15 ayat (1), Pasal 57 huruf f UU NO. 24 Tahun 2011 tentang Badan Penyelenggara Jaminan Sosial; dan Pasal 92 ayat (2) UU NO. 5 Tahun 2014 tentang Aparatur Sipil Negara. Dengan adanya keputusan MA Nomor 32P/HUM/2016 dan MK Nomor 98/PUU-XV/2017 yang menyatakan bahwa PP 70 Tahun 2015 tidak bertentangan dengan UU diatasnya dan maka dari itu pengelolaan JKK dan JKM bagi ASN tetap merupakan wewenang dari PT TASPEN, sehingga kepesertaan JKK dan JKM bagi ASN ada pada PT TASPEN. Dalam hal Pemberi Kerja ASN tidak memberikan jaminan sosial maka dapat mengajukan upaya administrasi.

\section{Daftar Bacaan}

\section{Jurnal}

Adrian E. Rompis, et al, 'Perbandingan Penyelesaian Sengketa Kepegawaian Melalui Gugatan Di Peradilan Tata Usaha Negara Dan Upaya Banding Administrasi Di Badan Pertimbangan Kepegawaian’ (2012), 6 Jurnal Kebijakan dan Manajemen PNS.

Budi Susanto, 'Analisis Yuridis Kewenangan Pengelolaan Program Jaminan Kecelakaan Kerja Bagi Aparatur Sipil Negara' (2017) 10 Arena Hukum.

R.Herlambang Perdana Wiratraman, 'Konstitusionalisme \& Hak-Hak Asasi Manusia Konsepsi Tanggung Jawab Negara Dalam Sistem Ketenagakerjaan’ (2005) 20 Jurnal Ilmu Hukum YURIDIKA.

\section{Laman}

Admin web TASPEN, ‘Sejarah perusahaan', <https://www.taspen.co.id/\# history? k=liqru $7>$ accesed 09 Februari 2020.

Admin web BPJS, 'ini Beda BPJS Ketenagakerjaan dan BPJS Kesehatan' (bpjsketenagakerjaan,2015)<https://www.bpjsketenagakerjaan.go.id/ 
berita/1253/Ini-Beda-BPJS Ketenagakerjaan-\&-BPJS-Kesehatan.html>, accesed 09 Februari 2020.

\section{Perundang-undangan}

Undang-Undang Dasar Negara Republik Indonesia Tahun 1945.

Undang-Undang Nomor 40 Tahun 2004 Tentang Sistem Jaminan Sosial (Lembaran Negara Republik Indonesia Tahun 2004 Nomor 150, Tambahan Lembaran Negara Republik Indonesia Nomor 4456 ).

Undang-Undang Nomor 24 Tahun 2011 Tentang Badan Penyelenggara Jaminan Sosial (Lembaran Negara Republik Indonesia Tahun 2011 Nomor 116, Tambahan Lembaran Negara Republik Indonesia Nomor 5256).

Undang-Undang Nomor 51 Tahun 2009 Tentang Peradilan Tata Usaha Negara (Lembaran Negara Republik Indonesia Tahun 2009 Nomor 160, Tambahan Lembaran Negara Republik Indonesia Nomor 5079).

Peraturan Pemerintah Nomor 70 Tahun 2015 Tentang Jaminan Kecelakaan Kerja dan Jaminan Kematian Bagi Aparatur Sipil Negara (Lembaran Negara Republik Indonesia Tahun 2015 Nomor 212, Tambahan Lembaran Negara Republik Indonesia Nomor 5740). 